\title{
Reports
}

\section{Post-Glacial History of Northumberland Strait Based on Benthic Foraminifera*:}

JILL H. E. M.CROBERTS

Department of Geology, Queen's University, Kingston, Ontario.

\section{Introduction}

Three sediment cores were examined for for aminiferal content to determine the postglacial history of Northumberland Strait. Northumberland Strait separates Prince Edward Island from the mainland of Nova Scotia and New Brunswick (Fig. 1) and is approximately 180 miles in length. Its width varies from 11 to 39 miles. The Strait shallows in its central portion, increasing in depth in the western and eastern ends where it merges with the Gulf of St. Lawrence. The Cape Breton submarine trough begins in the eastern end and terminates in the Laurentian channel, which passes north of the Strait. These troughs, as well as the irregular bottom topography, are attributed to the effects of Pleistocene glaciation of the region (Loring and Nota, 1966). Bottom lithology of the Strait ranges from coarse gravel, that is probably glacial in origin, to clay-size sediments, and its watermass is brackish due to the influence of the Gulf of St. Lawrence and fresh water inflow from rivers draining the bordering land.

The recent fauna in the Strait east of Cape Tormentine is dominantly arenaceous, consisting of Saccammina atlantica, Eggerella advena, Spiroplectammina biformis, Trochammina lobata, and Trochammina macresens. The fauna in the western portion, and in water shallower than ten fathoms, is dominantly calcareous-hyaline, consisting mainly of Elphidium clavatum, E. incertum, $E$. orbiculare and various arenaceous forms, in particular Eggerella advena. Three centimetres below the mud-water interface the sediments are barren or depauperate of fauna, consisting of one or two specimens of E. clavatum, E. orbiculare, or Eggerella advena. (Bartlett, personal communication).

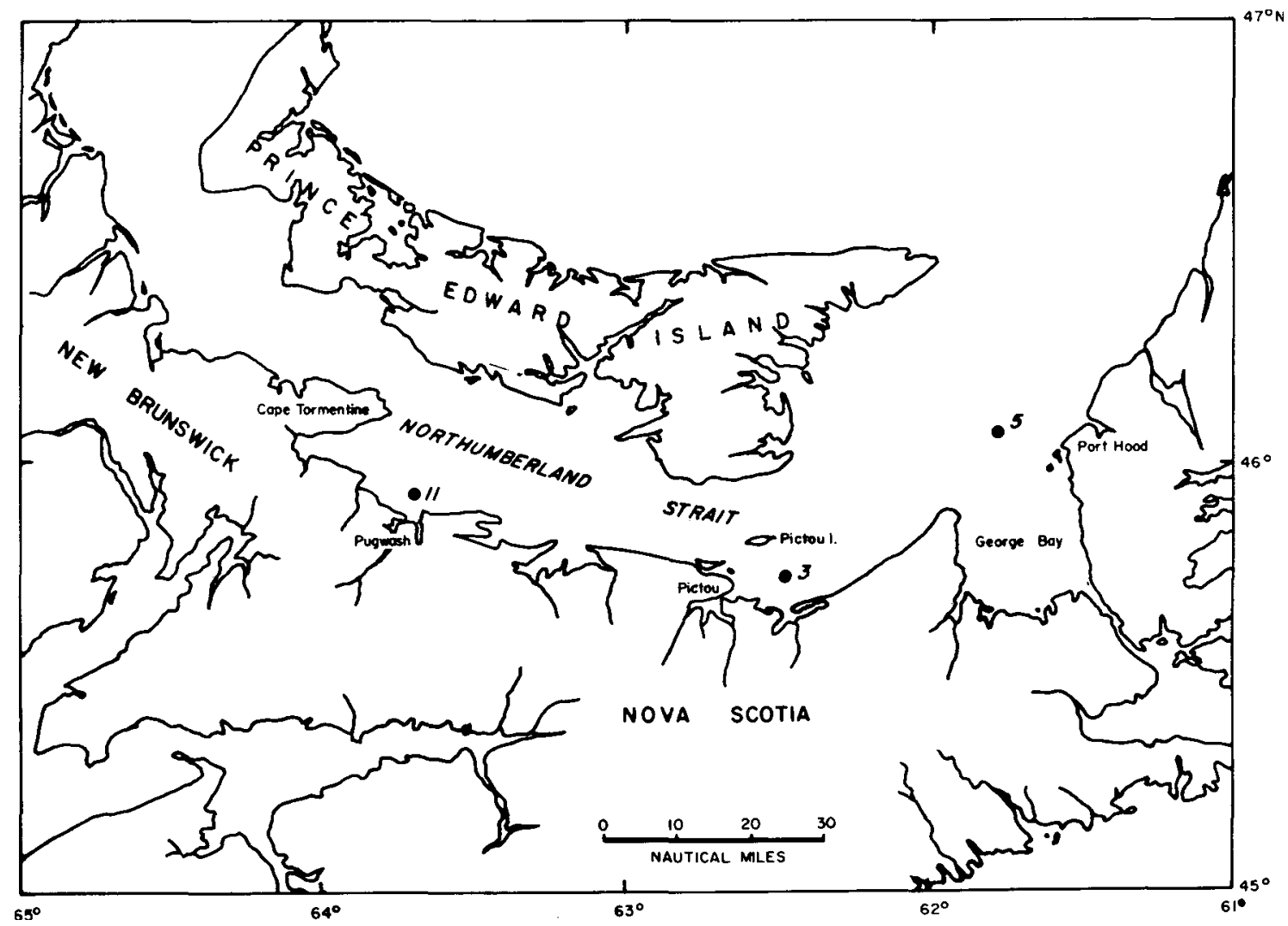

*Nanuscript received July $28,1968$. 
Method of Study

The three sediment cores were collected from the C.S.S. KAPUSKASING during May 1966, using a piston corer with a two and a half-inch core barrel. The cores were positioned as follows:

$\begin{array}{lllll} & \text { Latitude } & \text { Longitude } & \text { Depth } & \text { Length } \\ \text { Core } 11 & \frac{45^{\circ} 57^{\prime} 8^{\prime \prime} \mathrm{N}}{63^{\circ} 42^{\prime} 8^{\prime \prime} \mathrm{W}} & \frac{9 \mathrm{~m} .}{307 \mathrm{~cm}} & \\ \text { Core } 3 & 45^{\circ} 45^{\prime} 0^{\prime} \mathrm{N} & 62^{\circ} 28^{\prime} 6^{\prime \prime} \mathrm{W} & 24 \mathrm{~m} . & 388 \mathrm{~cm} . \\ \text { Core 5 } & 46^{\circ} 03^{\prime} 9^{\prime} \mathrm{N} & 61^{\circ} 44^{\prime} 7^{\prime \prime} \mathrm{W} & 48 \mathrm{~m} . & 810 \mathrm{~cm} .\end{array}$

The cores were logged and sampled during August of 1967 at the Bedford Institute where the sedimentological analysis was carried out.

The samples for faunal analysis were wet-sieved through two sieves - Tyler \#16 (.9801mm) and \# $230(.0628 \mathrm{~mm})$. The material remaining on the \#230 sieve was dried and the foraminiferal tests were floated from this material using carbon tetrachloride (specific gravity 2. 65). No more than 300 specimens were picked per sample. The foraminiferal analysis was conducted at Queen's University. Pollen analysis was kindly done by Dr. E. Stanley of the University of Georgia.

Sediment

The sediment in all three cores is generally similar. The predominant type is clayey silt. Sorting is poor to very poor, and all samples are positively skewed. This indicates (Folk and Ward, 1957) that most of the sediment was transported into a low energy environment where deposition was more operative then the winnowing action of currents (Bartlett, 1964; Duane, 1964)

Foraminifera

General:

The foraminiferal fauna in the cores is predominately calcareous-hyaline of which Elphidium is the major genus. The dominant species are Elphidium clavatum, E. incertum, E. orbiculare, and Bucella frigida. Arenaceous forms are relatively rare, and are represented $\overline{b y}$ Eggerella advena, Saccammina atlantica, Reophax scorpiurus, and Trochammina spp.

A comparison is made of the core fauna with present day foraminiferal assemblages (Table 1). Most of the species are recorded in the Arctic regions, except Trochammina macresens, T. ochracea, and Ammonia beccarii. However, all of the forms except Pyrgo williamsoni have been found by Bartlett $(1964 ; 1965 \mathrm{a}, \mathrm{b} ; 1966)$ in the cool temperate, brackish water of the Atlantic Provinces. A comparable fauna is found in warm temperature regions. However the fauna appears to have the closest affinity with the cool temperate environment of the Atlantic Provinces.

The faunal assemblages are sparse in both genera and species, consisting of ten genera and seventeen species. No samples generally contain less than five genera and commonly two. Faunas with less than twenty species inhabit water shallower than ten fathoms - the marginal marine facies (Walton, 1964). This is the most rigorous environment, since it is here that daily and seasonal fluctuations in temperature and salinity have the greatest effect. The marginalmarine facies is characterized by such nearshore features as bays, sounds, estuaries, intertidal marshes, and swamps.

The foraminiferal assemblages in the cores can be divided into: 1) a prolific Elphidium fauna in which E. clavatum, E. incertum, and E. orbiculare are the dominant species, with Bucella frigida as a minor constituent; and 2) a sparse Elphidium - Trochammina fauna. Both assemblages are found in core 3 and 11 , whereas only the latter type is found in core 5.

The Elphidium fauna occurs in greatest abundance at depths of less than five fathoms (Walton, 1964). In northern areas this fauna is the most extensive of the marginal marine faunas, and represents the transitional fauna between the marginal marine and open marine faunal groups. The Elphidium fauna is dominant in outer estuaries and inner lagoons, and indicates salinity above $20 \%$ (Bartlett, personal communication). 
The Elphidium fauna of the cores is similar to the fauna in the following environments: the nearshore facies of Long Island Sound (Buzas, 1965b); the shallow bay facies of Hudson Bay (Leslie, 1965); the bay facies of Barnstable, Massachusetts (Phleger and Walton, 1950). However, the fauna most closely resembles that of the Miramichi River Estuary, New Brunswick and the lagoonal environment of Tracadie Bay, Prince Edward Island (Bartlett, 1965a, 1966). Thus, ecological observations of the Miramichi assemblages should be valid for determining the paleoecology of the Elphidium fauna of the cores.

In his work, Bartlett (1965b) has observed a complete gradation between $\underline{E}$. clavatum and E. incertum and consequently he grouped them together in the E. incertum "complex". $\bar{A}$ ssemblages dominated by the E. incertum "complex" are prolific in baymouth environments on well-aerated, slightly turbulent, sand substrates, but also are found in large numbers on silt and silty clay throughout quiet central bays. The fauna at the mouth of the bay, and seaward from baymouth barriers is more diverse than the assemblages found inside the barrier with E. orbiculare, Bucella frigida and Eggerella advena as subordinate members. The inner bay fauna is less dominated by E. incertum "complex" and E. orbiculare. Eggerella advena, Bucella frigida and Trochammina spp. are minor constituents of the fauna.

The Trochammina fauna indicates a shallow subtidal environment such as the Spartina glabra zone (most seaward) of a tidal marsh. Usually the Trochammina fauna is associated with a Miliammina fauna (Said, 1953).

Sedimentary History of Northumberland Strait Core 11:

Core 11 was taken in nine metres of water. From the bottom of the core, 307 centimetres, to the peat horizon at 280 centimetres, the sediment is barren to depauperate of foraminifera, poorly sorted, positively skewed, and red. Little organic debris is present but there is a high concentration of fresh water diatoms. These features indicate a fluvial deposit. The peat horizon is dated at $3000^{ \pm}$years B.P., and appears to have been derived from two source areas. This horizon is now 11.8 metres below sea level, consequently sea level must have been 11.8 metres lower at the time of deposition. A sand layer overlies the peat, and contains turitellids as well as a foraminiferal fauna indicative of an inner bay environment. In addition, the grain size, sorting, and skewness of the sediment is characteristic of a lagoonal deposit. Above the sand there is a shell horizon consisting of Crassostrea virginica, Crepidula fornicata, Balanus balanus, and turitellids which are characteristic bank formers in warm quiet shallow-water lagoons.

From the top of the peat layer $(280 \mathrm{~cm})$ to 140 centimetres a prolific Elphidium fauna persists, except for a barren interval at 160 centimetres (Fig. 2). The fauna is dominated by Elphidium incertum "complex" and $E$. orbiculare. Upward from the peat horizon the hardier form E. clavatum becomes dominant over E. incertum, in conjunction with a decline in importance of $\underline{E}$. orbiculare. This indicates a transition to more turbulent conditions in a lagoonal environment. Also the smaller tests of $\underline{E}$. clavatum suggest that the habitat is more favourable for this species.

An abrupt break in the fauna, along with a marked increase in the organic content of the sediment occurs at 160 centimetres (sample 9). This may be the result of an unfavourable anaerobic environment produced by decomposition of abundant plant matter. Above this the fauna returns.

From 140 centimetres to the top of the core the depauperate fauna is similar to the present day conditions of Northumberland Strait.

Core 3:

Core 3 was taken east of Pictou, Nova Scotia, in 24 metres of water. The bottom of the core $(388 \mathrm{~cm})$ penetrates sediment with a prolific Elphidium fauna, dominated by E. clavatum. This indicates turbulent brackish water. Overlying this is a barren to depauperate section bounded by upper and lower peat layers $(240$ and $377 \mathrm{~cm})$. The absence of a transition fauna as the environment shifted from marine to fresh water may be attributed to the rapidity of the event, or loss of material during subaerial exposure. 


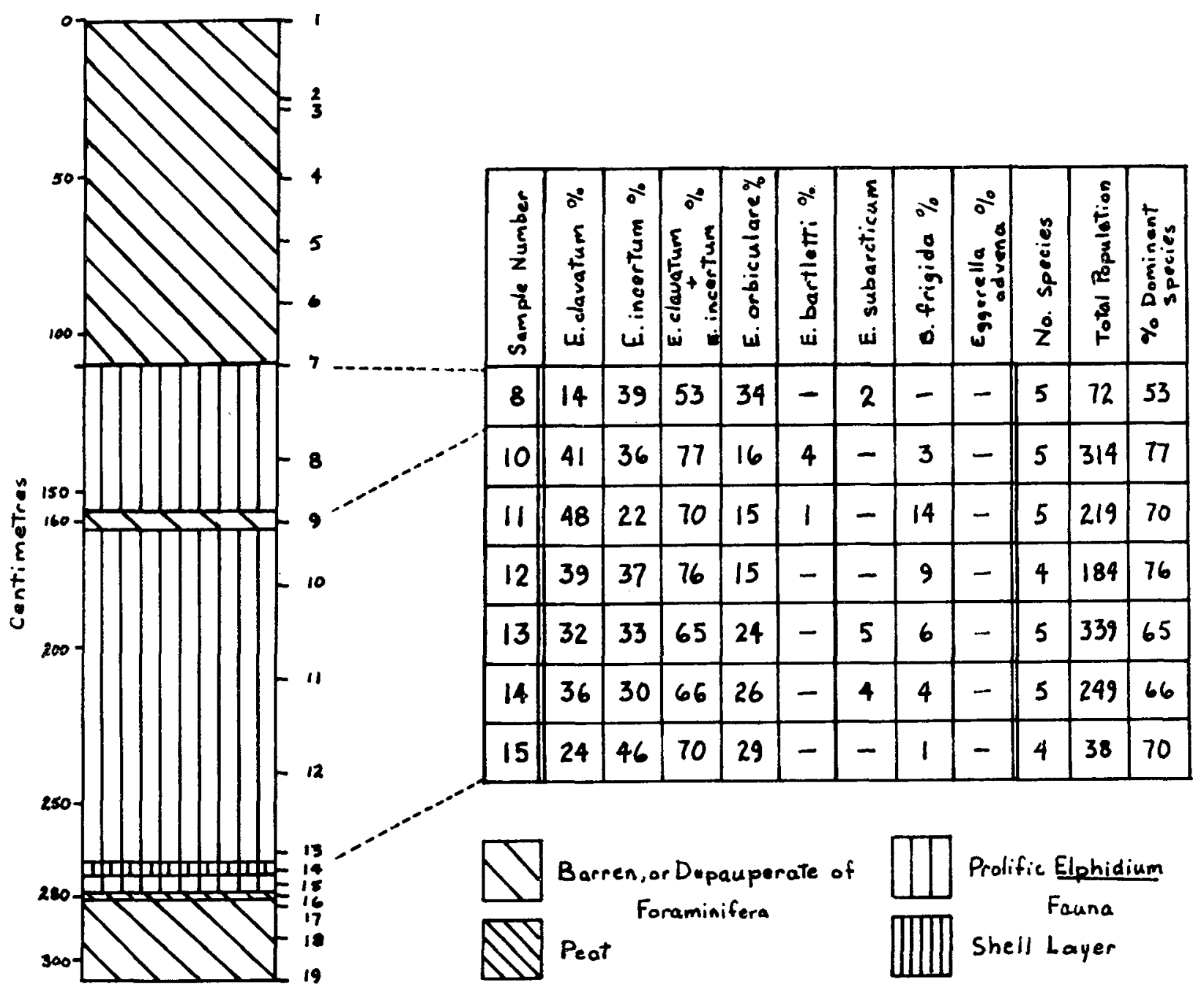

Fig. 2 - Position and percentage of foraminifera species in Core II 
The lower peat layer $(377 \mathrm{~cm})$ represents the Plsietocene $B$ pollen zone, indicating warmer than present conditions. The horizon is dated at $5200 \pm$ years B.P., corresponding with the warmest part of the Hypsithermal of Flint and Brandtner (1961).

The barren to depauperate section between the peat layers may be a result of unfavourable conditions. However, the brackish water of present day high marsh facies, usually supports an arenaceous fauna of Miliammina and/or Trochammina. The absence of foraminifera suggests that diagenesis has destroyed much of the population. Leaching during the formation of the upper peat layer or an increase in acidity within the sediment may account for the destruction of some of the tests. Many of the calcareous and arenaceous species are known to have a tectin or pseudo-chitin inner lining, that is indestructable even when treated with hydrofluoric acid (Van Veen, 1957). Thus, if the fauna were present, the inner linings may have been overlooked or destroyed when examining the cores.

The interval from the upper peat layer $(240 \mathrm{~cm})$ to 140 centimetres contains a prolific Elphidium fauna, and numerous shell layers (Fig. 3). The shell layers, dominated by Crassostrea virginica and associated with Ammonia beccarii, indicate warmer than present conditions. Lower than optimum salinity is probably responsible for the heavier, large Elphidium forms observed. Also, the association with Trochammina species suggests low salinity.

The Elphidium fauna is dominated by $\underline{E}$. clavatum suggesting a high energy environment. However, the low frequency of Bucella frigida and the presence of shell layers indicates a semirestricted brackish water environment. The shell layers alternate with sediment which may be the result of a migrating channel through the oyster bank (Fig. 3). At the top of the interval the

increased importance of $\underline{\mathrm{E}}$. incertum in association with Trochammina spp. marks a decrease in salinity.

At 140 centimetres, there is an abrupt decline in for aminiferal population and number of species. No lithological or sedimentological change was observed to account for this. However, the few tests present show signs of secondary calcification. Bradshaw (1957, 1961) noted that tests of Ammonia beccarii tepida dissolved under conditions of low $\mathrm{pH}$, but the individual is able to survive, and on return to normal $\mathrm{pH}$ is able to recalcify its test. Thus, secondary calcification indicates that during the lifetime of the fauna the $\mathrm{pH}$ or salinity dropped causing some test solution, and subsequent return of saline waters permitted the surviving forms to redeposit their tests.

From 140 centimetres to 54 centimetres, there is a reappearance of the Elphidium fauna with associated shell horizons. The absence of Ammonia beccarii, in conjunction with heavier, more robust Elphidium tests indicate a cooler climate. The Elphidium fauna dominated by E. clavatum and the shell horizons suggest an environment similar to the one before the break.

At 54 centimetres, the fauna is depauperate. The sparse Elphidium fauna is associated with Eggerella advena and Saccammina atlantica which is characteristic of present conditions in Northumberland Strait.

\section{Core 5:}

Core 5 was taken in 48 metres of water. The core lacked sufficient fauna to enable a definite paleoecological reconstruction.

\section{Correlation of the Cores}

Only two of the cores can be correlated. Cores 3 and 11 contain a comparable prolific brackish water Elphidium fauna as well as fresh water peat deposits (Figs. 2 and 3 ).

Because the sediments of the cores are uniform in character, the as sumption is made that the forces acting on the system would also be uniform, and thus deposition would occur at a constant, though not necessarily equal, rate. In Core 11 the average sedimentation $r$ ate above the peat horizon at 280 centimetres $(3000 \pm$ B. P. $)$ is calculated to be 9.3 centimetres/hundred 


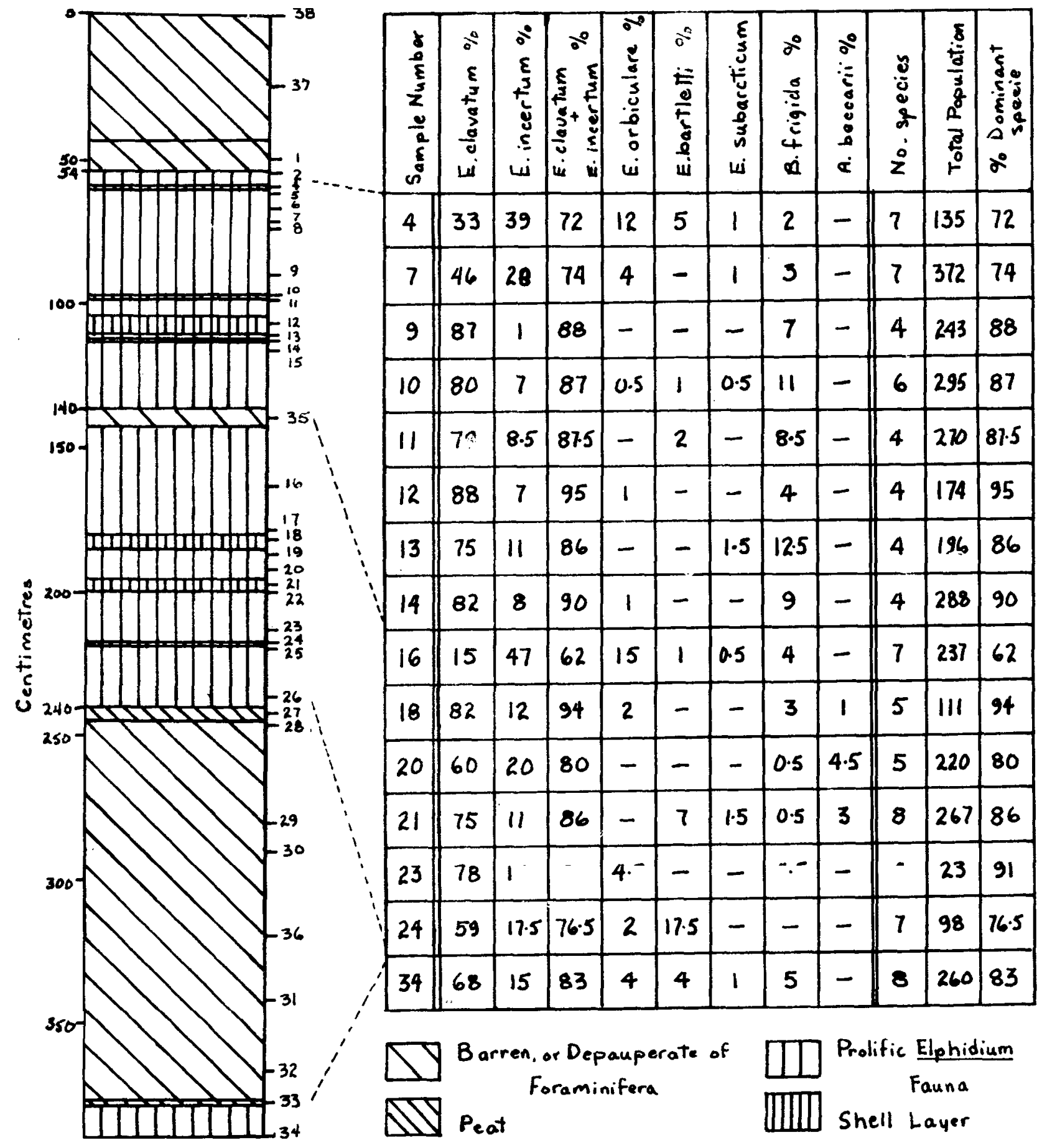

Fig. 3. Position and percentage of foraminifera species in Core 3 
years. From this the faunal break at 160 centimetres is calculated as $1714 \pm B$. P. Similarly, in Core 3 the sedimentation rate above the lower peat layer (377 centimetres, $5200 \pm B . P$.$) is$ 7.3 centimetres/hundred years. The upper peat layer dates at $3200 \pm B$. P. and the faunal break at $1750 \pm B . P$. The peat layer in core 11 and the upper peat layer in core 3 appear to be contemporaneous, as does the faunal break in core 3 at 140 centimetres and in core 11 at 160 centimetres.

The post-glacial history of Northumberland Strait may be postulated as follows: immediately after the deglaciation of the area, sea level was lower by approximately 71 metres ( $300 \mathrm{feet}$ ). At this time the Strait would be completely exposed to subaerial influences. Drainage of the area was most likely to the north through the Cape Breton trough to the Laurentian Channel. Inundation of the area by marine waters about 11, 800 years B. P. flooded the Strait and opened the Isthmus of Chignecto. As conditions became warmer, Crassostrea virginica and Ammonia beccarii migrated into the region. Isostatic rebound in the area resulted in the closure of the Is thmus of Chignecto at $6400 \pm$ B.P. (Bartlett, personal communication) and exposed the regions of core 3 and 11 to fresh water influence. At this time, water may haye continued to drain through the Cape Breton trough. After $3000 \pm$ B. P. marine waters again invaded the Strait. A reversal, in conjunction with a fresh water influx around $1700 \pm B$. $R$. resulted in a decline in the foraminiferal populations. This was followed by a brief period of more favourable conditions. The appearance of the depauperate fauna marked the onset of present Nor thumberland Strait conditions.

\section{Acknowledgements}

The writer thanks Miss Kate Kranck of the Atlantic Oceanographic Laboratory, Dartmouth, N.S. for providing the three sediment cores, sedimentological data, as well as topographic information of Northumberland Strait. Special thanks are due Dr. G. A. Bartlett of the Atlantic Oceanographic Laboratory for supervision, suggestions, and help in species identification; Dr. R. G. Greggs of Queen's University for guidance throughout the year and critical reading of the manuscript. The help of the master and crew of the C. S. S. KAPUSKASING during the collection of the cores is greatly appreciated. The writer also thanks the Atlantic Oceanographic Laboratory for making the research project possible.

\section{References cited}

BARTLETT, G. A., 1963, A preliminary study of foraminifera distribution on the Atlantic continental shelf, southeastern Nova Scotia, (unpublished manuscript), Report B. I. O. $63-3$, pp. $1-22$.

1964, Benthonic foraminiferal ecology in St. Margaret's Bay and Mahone Bay, southe ast Nova Scotia, (unpublished manuscript), Report B. I. O. 64-8, pp. 1-162.

, 1965a, Preliminary investigation of benthonic foraminiferal ecology in Tracadie Bay, Prince Edward Island, (unpublished manuscript), Report B. I. O. 65-3, pp. $1-57$.

, 1965b, Preliminary notes on recent species of Elphidiidae in shallow waters of the Atlantic Provinces of Canada, (unpublished manuscript), Report B. I. O. 65-13, pp. $1-30$.

, 1966, Distribution and abundance of foraminifer a and Thecamoebina in Miramichi River and Bay, (unpublished manuscript), Report B. I. O. 66-2, pp. $1-107$.

BRADSHAW, J.S., 1957, Laboratory studies on the rate of growth of the foraminifera, Streblus beccarii (Linné) var. tepida (Cushman), Jour. Paleo., vol. 31, no. 6, pp. 11381147.

, 1961, Laboratory experiments on the ecology of foraminifera, Cont. Cushman Found. Foram. Res., vol. 12, pt. 3, pp. 87-106.

BUZAS, M. A., 1965, The distribution and abundance of foraminifera in Long Island Sound, Smithsonian Misc. Coll., vol. 149, no. 1, pp. 1-89. 
DUANE, D. B. , 1964, Significance of skewness in recent sediments, Western Pamlico Sound, North Carolina, Jour. Sed. Pet., vol. 34, pp. 864-874.

FLINT, R. F. and BRANDTNER, F., 1961, Climatic changes since the last interglacial, Amer. Jour. Sci. , vol. 259, pp. 321-328.

FOLK, R. L. and WARD, W. C. , 1957, Brazos River Bar: A study in the significance of grain size parameters, Jour. Sed. Pet., vol. 27, pp. 3-26.

LESLIE, R. J., 1965, Ecology and paleoecology of Hudson Bay foraminifera (unp ublished manuscript), Report B. I. O. 65-6, pp. 1-191.

LORING, D.H. and NOTA, D.J.G., 1966, Sea floor conditions around the Magdalen Islands in the Southern Gulf of St. Lawrence, Jour. Fish. Res. Bd. Canada, vol. 23, no. 8, pp. $1197-1207$.

PHLEGER, F.B., and WALTON, W. R., 1950, Ecology of marsh and bay foraminifera, Barnstable, Massachusetts, Amer. Jour. Sci., vol. 248, pp. 274-294.

SAID, R., 1953, Foraminifera of Great Pond East Falmouth, Massachusetts, Cont. Cushman Found. Foram. Res., vol. 4, pt. 1, pp. 1-14.

VanVEEN, F.R., 1967, Microforaminifera, Micropaleontology, vol. 3, no. 1, p. 74.

WALTON, W. R., 1964, Recent for aminiferal ecology, approaches to paleoecology, Edited by John Imbrie and Norman Newell, Wiley and Sons, Inc., pp. 151-237.

\section{Faunal Reference List}

Ammonia beccarii (Linné): Nautilus beccarii Linné, 1758, Test. Brit. Supp., p. 710.

Bucella frigida(Cushman): Pulvinulina frigida Cushman, 1922, Cont. Can. Biol., no. 9 (1921), p. 144 .

Eggerella advena (Cushman): Verneuilina advena Cushman, 1922, Cont. Can. Biol., no. 9 (1921), p. 141 .

Elphidium bartletti Cushman, 1933, Smithsonian Misc. Coll, , vol. 89, 'no. 9, p. 4, p1. 1, fig. 9. Elphidium clavatum (Cushman): Elphidium incertum (Williamson) var. clavatum Cushman, 1930, U.S. Nat. Mus. Bull. 104, pt. 7, pl. $\overline{7, \text { fig. } 10 .}$

Elphidium incertum (Williamson): Elphidium umbilicatula (Walker) var. incerta Williamson, 1858, Recent foraminifer a of Great Britain, p. 44, pl. 3, fig. 82 a.

Elphidium orbiculare (Brady): Nonionina orbicularis Brady, 1881, Ann. Mag. Nat. Hist., ser. 5, vol. 8, p. 415, pl. 21 , fig. $5 \mathrm{a} \& \mathrm{~b}$.

Elphidium subarcticum Cushman, 1944, Cushman Lab. Foram. Res. Spec. Pub. 12, p. 27, pl. 3, figs. 34, 35 .

Quinqueloculina seminulum (Linné): Serpula seminulum Linné, 1788, in Systema naturae sive regna tria naturae, atc. Edn. XIII, by J.F. Gmelin, 10 vols. Leipzig, $1788-93$, p. 3439 , no. 2 .

Reophax scorpiurus Montford, 1808, Conchyliologie systematique...., v. I, p. 330.

Saccammina atlantica (Cushman): Proteonina atlantica Cushman, 1944, Spec. Pub. 12, Cushman Lab. Foram. Res., p. 5, p1. 1, fig. 4.

Trochammina lobata Cushman, 1944, Spec. Pub. 12, Cushman Lub. Foram. Res., p. 18, pl, 2, fig. 10 .

Trochammina macrescens Brady (1870): Trochammina inflata (Montagu) var. macrescens Brady, 1870, Ann. Mag. Nat. Hist., ser. 4, vol. 6, p. 51, pl. 11, figs. 5a-c.

Trochammina ochracea (Williamson), 1858: Rotalia ochracea Williamson, 1858, The Roy. Soc., p. 55, p1. 4, fig. 112 , p1. 5, fig. 113.

Trochammina squamata Jones and Parker, 1860, Geol. Soc. London, Quart. Jour., vol. 16, p. 304 . 